\title{
Comparative Study of Cyanobacterial and E. coli RNA Polymerases: Misincorporation, Abortive Transcription, and Dependence on Divalent Cations
}

\author{
Masahiko Imashimizu, ${ }^{1,2}$ Kan Tanaka, ${ }^{3}$ and Nobuo Shimamoto ${ }^{1,4}$ \\ ${ }^{1}$ Structural Biology Center, National Institute of Genetics, and Department of Genetics, The Graduate University for Advanced Studies, \\ Mishima, Shizuoka 411-8540, Japan \\ ${ }^{2}$ Gene Regulation and Chromosome Biology Laboratory, National Cancer Institute at Frederick, MD 21702, USA \\ ${ }^{3}$ Graduate School of Horticulture, Chiba University, 648 Matsudo, Matsudo-shi, Chiba 271-8518, Japan \\ ${ }^{4}$ Faculty of Life Sciences, Kyoto Sangyo University, Kamigamo-Motoyama, Kita-Ku, Kyoto 603-8555, Japan
}

Correspondence should be addressed to Nobuo Shimamoto, nshima@cc.kyoto-su.ac.jp

Received 7 June 2011; Accepted 31 July 2011

Academic Editor: Sebastián Chávez

Copyright ( $) 2011$ Masahiko Imashimizu et al. This is an open access article distributed under the Creative Commons Attribution License, which permits unrestricted use, distribution, and reproduction in any medium, provided the original work is properly cited.

If $\mathrm{Mg}^{2+}$ ion is replaced by $\mathrm{Mn}^{2+}$ ion, RNA polymerase tends to misincorporate noncognate nucleotide, which is thought to be one of the reasons for the toxicity of $\mathrm{Mn}^{2+}$ ion. Therefore, most cells have $\mathrm{Mn}^{2+}$ ion at low intracellular concentrations, but cyanobacteria need the ion at a millimolar concentration to maintain photosynthetic machinery. To analyse the mechanism for resistance against the abundant $\mathrm{Mn}^{2+}$ ion, we compared the properties of cyanobacterial and E. coli RNA polymerases. The cyanobacterial enzyme showed a lower level of abortive transcription and less misincorporation than the E. coli enzyme. Moreover, the cyanobacterial enzyme showed a slower rate of the whole elongation by an order of magnitude, paused more frequently, and cleaved its transcript faster in the absence of NTPs. In conclusion, cyanobacterial RNA polymerase maintains the fidelity of transcription against $\mathrm{Mn}^{2+}$ ion by deliberate incorporation of a nucleotide at the cost of the elongation rate. The cyanobacterial and the E. coli enzymes showed different sensitivities to $\mathrm{Mg}^{2+}$ ion, and the physiological role of the difference is also discussed.

\section{Introduction}

A DNA-dependent RNA polymerase (RNAP) has a catalytic center chelating $\mathrm{Mg}^{2+}$ ions to form phosphodiester bonds $[1,2]$. Most other divalent cations inhibit the activity, but $\mathrm{Mn}^{2+}$, which has a similar but only slightly larger ionic radius than $\mathrm{Mg}^{2+}$, supports the polymerizations. In the case of Escherichia coli (Esc) RNAP, $\mathrm{Mn}^{2+}$ causes the enzyme to misincorporate deoxyribonucleoside triphosphate (dNTP) instead of ribonucleoside triphosphate (NTP) [3] as well as noncognate NTPs [4-6]. Therefore, the growth of E. coli is inhibited in the presence of $\mathrm{Mn}^{2+}$, and the inhibition is mitigated by GreA and GreB which bind to RNAP [7].

In cyanobacteria, the intracellular concentration of $\mathrm{Mn}^{2+}$ is considered to be higher by two orders of magnitude than in
E. coli [8], because $\mathrm{Mn}^{2+}$ is required at higher concentrations to assemble the photosynthetic reaction center carrying $\mathrm{Mn}^{2+}$ cluster, and/or to scavenge reactive oxygen species generated from photosynthesis $[9,10]$. Since cyanobacteria have no genes orthologous to gre $A$ or gre $B$, cyanobacteria should have the mechanism of detoxifying $\mathrm{Mn}^{2+}$.

We thus made two purified reconstituted transcription systems from a mesophilic cyanobacterial species, Synechococcus sp. PCC 7942 (Syn), and from a moderately thermophilic species, Thermosynechococcus elongatus BP-1 (The). By comparing these systems with the system of E. coli, we here examine the possibility that the mechanism of detoxifying $\mathrm{Mn}^{2+}$ is installed in the poisoning target, RNAP, and ask whether or not the cyanobacterial RNAP has a sensitivity to $\mathrm{Mg}^{2+}$ different from that of $E$. coli RNAP. 


\section{Materials and Methods}

2.1. Materials. All of the oligo DNAs and RNA, NTPs, and $\left[\gamma^{-32} \mathrm{P}\right]$ ATP were obtained from Hokkaido System Science, Yamasa and Perkin Elmer, respectively. Restriction enzymes were purchased from New England Biolabs and Takara. Primestar HS and Primestar Max DNA polymerases used for PCR were purchased from Takara. Syn cells used for RNAP purification were partially gifted from Dr. Mitsumasa Hanaoka. The culture condition of the gifted cells is the same as shown in the next section.

2.2. Protein Purification. Cells of Syn and The were cultivated and harvested as described $[15,16]$. About $10 \mathrm{~g}$ of the wetcell paste was suspended in $30 \mathrm{~mL}$ of TGED buffer [ $10 \mathrm{mM}$ Tris- $\mathrm{HCl}(\mathrm{pH}$ 8.0), 5\% (v/v) glycerol, $0.1 \mathrm{mM}$ EDTA, and $1 \mathrm{mM}$ DTT] containing $1 \mathrm{mM}$ phenylmethylsulfonyl fluoride and $0.2 \mathrm{M} \mathrm{NaCl}$, and then, cells in suspension were lysed by sonication. A 35\%- saturated solution of ammonium sulfate was added to a soluble fraction of the cell lysate which was obtained by centrifuging for $30 \mathrm{~min}$ at $20,000 \times \mathrm{g}$. The obtained mixture was added to $10 \mathrm{~mL}$ of phenyl sepharose resin (GE Healthcare), pre-equilibrated with the TGED buffer containing $0.2 \mathrm{M} \mathrm{NaCl}$ and $35 \%$ saturated ammonium sulfate, and the mixture was washed by the same buffer, eluted with the TGED buffer. The eluate was applied to a column containing $10 \mathrm{~mL}$ of DEAE resin (TOSOH) preequilibrated with the TGED buffer, and the column was washed with TGED buffer containing $0.2 \mathrm{M} \mathrm{NaCl}$, eluted with the TGED buffer containing $0.5 \mathrm{M} \mathrm{NaCl}$. The eluted fraction was further chromatographically purified by using Hi-trap heparin affinity column (GE Healthcare) and MonoQ anion exchange column (GE Healthcare) as described [16]. The purified core enzyme was dialyzed against the TGED buffer containing $0.2 \mathrm{M} \mathrm{NaCl}$ and $50 \%$ glycerol and stored at $-80^{\circ} \mathrm{C}$. The core enzyme of $E$. coli was prepared according to [17], and $\sigma^{70}$ of E. coli and $\sigma^{A}$ s of Syn and The were obtained as described in $[15,16]$.

2.3. In Vitro Transcription Assays. The liner DNA template containing the T7A 1 promoter from -147 to +87 , when +1 is the transcription start site, was prepared by PCR using the plasmid pAR1435 [18] and the following digestion by HaeIII. The template containing the psbA2 promoter from -127 to +101 was prepared by PCR using a genomic DNA of a cyanobacterium Synechocystis sp. PCC 6803. These DNA templates were purified by PAGE. The holoenzyme was reconstituted by incubating core RNAP mixed with a 3 -fold molar excess of the primary $\sigma$ factor for $10 \mathrm{~min}$ at $37^{\circ} \mathrm{C}$. We used twice more Syn and The RNAPs, because they have smaller affinities for the $p s b A 2$ promoter. The reconstituted holoenzyme $(50 \mathrm{nM}$ for E. coli or $100 \mathrm{nM}$ for Syn and The) and $20 \mathrm{nM}$ DNA template was preincubated for $10 \mathrm{~min}$ at $37^{\circ} \mathrm{C}$ in $8 \mu \mathrm{L}$ of T-buffer [ $50 \mathrm{mM}$ Tris- $\mathrm{HCl}$ (pH 7.9), $100 \mathrm{mM} \mathrm{KCl,} 10 \mathrm{mM} \mathrm{MgCl}_{2}$ (see figure legends and the main text in the cases that the concentration was changed or $\mathrm{MgCl}_{2}$ was changed to $\mathrm{MnCl}_{2}$ ), $1 \mathrm{mM}$ DTT, and $150 \mu \mathrm{g} \mathrm{mL}^{-1}$ partially hydrolysed casein]. Reaction was started by adding $2 \mu \mathrm{L}$ of prewarmed substrate mixture: $5 \mu \mathrm{M}$ $\left[\gamma^{-32} \mathrm{P}\right]$ ATP $\left(40 \mathrm{Ci} \mathrm{mmol}^{-1}\right)$ as well as $100 \mu \mathrm{M}$ each of GTP, CTP, and UTP. In a single-round reaction, heparin $(100 \mu \mathrm{g}$ $\mathrm{mL}^{-1}$ ) was added together with the substrates to eliminate enzyme turnover. After incubation for $20 \mathrm{~min}$ at $37^{\circ} \mathrm{C}$, the reaction was stopped by phenol/chloroform/isoamyl alcohol $(25: 24: 1)$. Transcripts were analyzed by PAGE using a $20 \%$ gel containing $7 \mathrm{M}$ urea. The sequences of abortive transcripts from the T7A1 promoter were assigned according to [19], and those from the $p s b A 2$ promoter were determined using $5^{\prime}$ end-labeled RNA marker $5^{\prime}$-AGUCAGUU- $3^{\prime}$ and a chemical cleavage assay (Figure S2 which is available online at doi:10.4061/2012/572689).

All the experiments with presented results in this study were repeated two or more times and the represented ones are shown.

2.4. TEC Formation. In order to stop elongation at Position +18 by a lack of the cognate CTP for Position +19 , the intrinsic cytosine residues (nontemplate strand) at Positions $+4,+9,+10$, and +14 of the $p s b A 2$ promoter were replaced by thymine by PCR-based mutagenesis, following cloning of the DNA template from -127 to +101 into a plasmid pUC19 (see Figure 4(a)). For the TEC9 formation, the intrinsic cytosine residues at Positions +10 and +14 were retained. The binary complex was formed by mixing the holoenzyme (50 nM for E. coli or $100 \mathrm{nM}$ for Syn) and $40 \mathrm{nM}$ DNA template containing the $p s b A 2$ promoter as described above. The ternary complex was formed by incubating $5 \mathrm{~min}$ at $37^{\circ} \mathrm{C}$ with $5 \mu \mathrm{M}\left[\gamma^{-32} \mathrm{P}\right] \mathrm{ATP}\left(40 \mathrm{Ci} \mathrm{mmol}^{-1}\right)$ as well as $50 \mu \mathrm{M}$ each of GTP and UTP in T-buffer containing $10 \mathrm{mM} \mathrm{MgCl}_{2}$ or $1 \mathrm{mM} \mathrm{MnCl}$. The TEC was isolated from the substrates including $\left[\gamma_{-}{ }^{32} \mathrm{P}\right]$ ATP as well as released abortive transcripts by triplicated passing through a MicroSpin G50 column (GE Healthcare) equilibrated with T2-buffer $[50 \mathrm{mM}$ Tris$\mathrm{HCl}$ (pH 7.9), $100 \mathrm{mM} \mathrm{KCl}, 10 \mathrm{mM} \mathrm{MgCl} 2$ or $1 \mathrm{mM} \mathrm{MnCl} 2$, $1 \mathrm{mM} \mathrm{DTT}$, and 5\% glycerol] at room temperature. After this treatment, no elongations by the TEC9s and TEC18s of both Syn and E. coli in the T2 buffer were detected for $10 \mathrm{~min}$ at $37^{\circ} \mathrm{C}$, without adding substrates.

2.5. Single-Step Elongation Assay. Reactions were started by adding cognate or noncognate NTP at the final concentration of $0.5 \mathrm{mM}$ to $9 \mu \mathrm{L}$ solution containing the TEC and the T2-buffer. The obtained mixture was incubated at $37^{\circ} \mathrm{C}$ for the indicated time and the reaction was stopped by adding an equal volume of gel-loading solution, containing $95 \%(\mathrm{v} / \mathrm{v})$ deionized formamide, $20 \mathrm{mM}$ EDTA ( $\mathrm{pH}$ 8.0), bromophenol blue and xylene cyanol, $0.05 \%(\mathrm{w} / \mathrm{v})$ each, and analyzed by PAGE using a 20\% gel containing $7 \mathrm{M}$ urea.

\section{Results}

3.1. Cyanobacterial Transcription System Reconstituted from Purified Components. For the comparative study, it is essential to purify cyanobacterial RNAPs. The tedious step of 

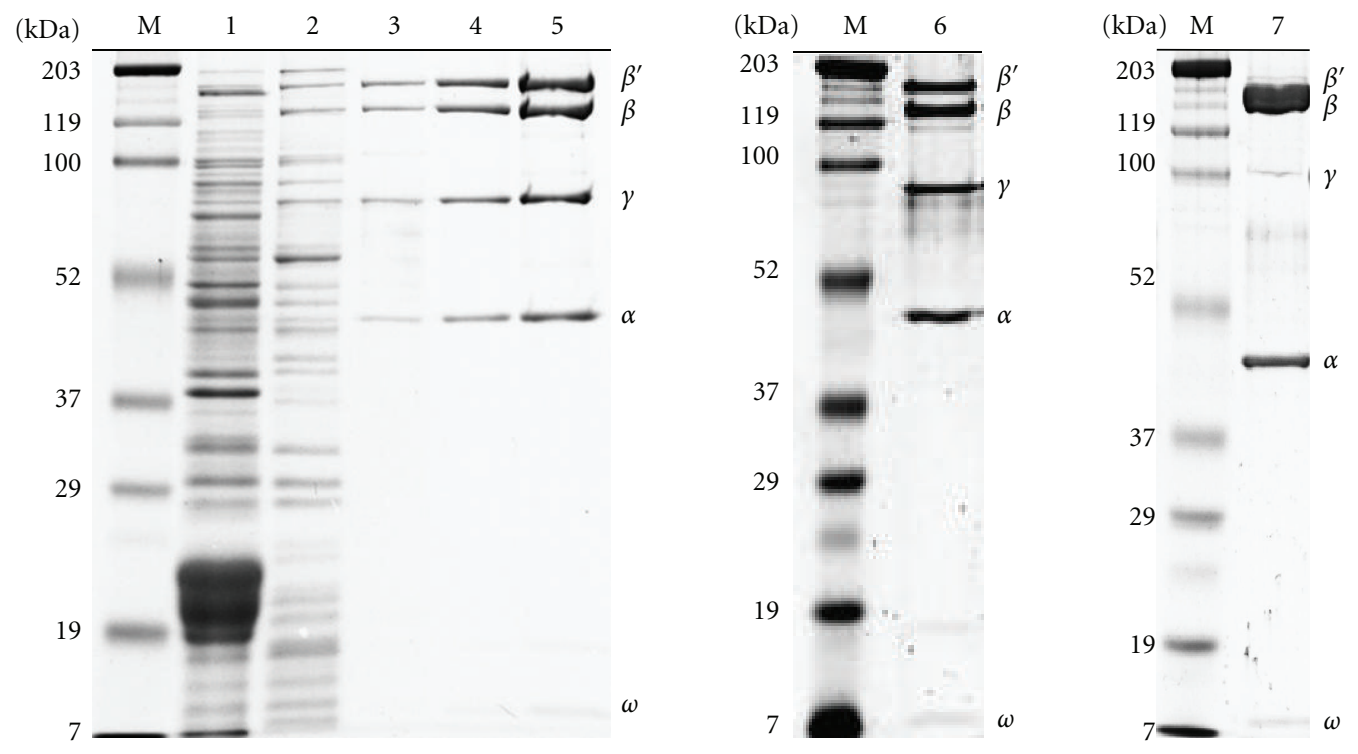

(a)

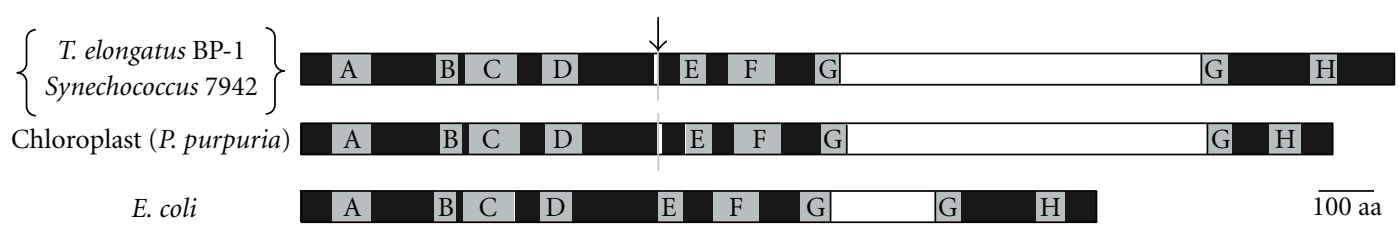

(b)

Figure 1: Cyanobacterial RNAPs. (a) Analysis of the fractions of The core enzyme by 10\% SDS-PAGE after the treatment of hydrophobic resin (lane $1: 26.9 \mu \mathrm{g}$ ), DEAE anion-exchange (lane $2: 7.0 \mu \mathrm{g}$ ), heparin affinity (lane $3: 0.8 \mu \mathrm{g}$ ), and MonoQ chromatography (lane $4: 1.6 \mu \mathrm{g}$ ). Lanes 5-7 show $7.5 \mu \mathrm{g}$ of the purified The, Syn, and E. coli enzymes used in transcription assays. Marker proteins (BIO-RAD) are also shown in lane $\mathrm{M}$ with the molecular weights indicated in the left margin. The gel was stained with Coomasie Brriliant Blue. (b) Schematic diagrams of $\beta^{\prime}$ subunits of The, Syn, a chloroplast of red alga Porphyra purpurea, and E. coli. The conserved regions A-H $[11,12]$ were also indicated. The white boxes represent the nonconserved domain inserted in Region G [13, 14]. The split sites are indicated by an arrow. The scale bar of 100 amino-acid residues (aa) is indicated at the bottom.

the purification is to remove thylakoid-membrane fragments and the associated proteins $[20,21]$. We thus invented a batch-wise removal with a hydrophobic resin (see Materials and methods). The Syn and The core enzymes were purified by the improved procedure, resulting in a preparation which is more than $95 \%$ pure, judged by CBB stain, within a day (Figure 1(a)). The core enzyme of cyanobacteria is composed of $\alpha_{2} \beta \beta^{\prime} \omega$ as E. coli enzyme, but its $\beta^{\prime}$ subunit is composed of two polypeptides [20]. A large nonconserved domain is inserted in the G region as chloroplast RNAP (Figure 1(b)) [21].

We examined the transcription by the holoenzymes of Syn, The, and E. coli retaining their primary $\sigma$ factors $\left(\sigma^{s}\right.$ and $\sigma^{70}$ ) at the T7A1 promoter (Figure 2(a)), which is the strongest among the standard promoters for the E. coli enzyme [22]. The Syn enzyme was active on this transcription unit but much weaker than the E. coli enzyme: the runoff transcript was observed only at the multiround condition, and its amount was lower by an order of magnitude (Figure 2(b)). Moreover, the The enzyme did not synthesize any detectable transcripts in all conditions (data not shown).
We thus searched for a promoter driving transcription by both cyanobacteria and E. coli holoenzymes without adding specific activators. The cyanobacterial $p s b A 2$ gene encoding D1 protein of the photosystem II is highly transcribed in the daytime [23] and the sequence of its promoter shares the -10 and -35 elements recognized by the $E$. coli $\sigma^{70}$ holoenzyme (Figure 2(a)) [24]. As expected, the E. coli enzyme was active on this promoter and produced similar amounts of runoff transcripts from the $p s b A 2$ promoter in the single-round condition (Figure 2(c)). We thus used this promoter in comparison between these enzymes.

3.2. Cyanobacterial RNAPs Are Less Abortive due to Their Core Parts. In contrast to the similar amounts of runoff transcript, Syn RNAP produced a much lower level of 2-11 nt long transcripts (Figure 2(c)), which is known as abortive transcription, an iterative synthesis and release of oligo-RNA in initiation $[25,26]$. The ratio of abortive synthesis to runoff synthesis is smaller than that in E. coli by two orders of magnitude. The ratio for The RNAP could be determined only in a multiround transcription condition and was as low as that of Syn RNAP (Figure 2(c)). 
T7A1 gtattgacttaaagtctaacctataggatacttacagccATCGAGAGGG psbA2 agctttacaaaactctcattaatcctttagactaagttAGTCAGTTCCA

(a)

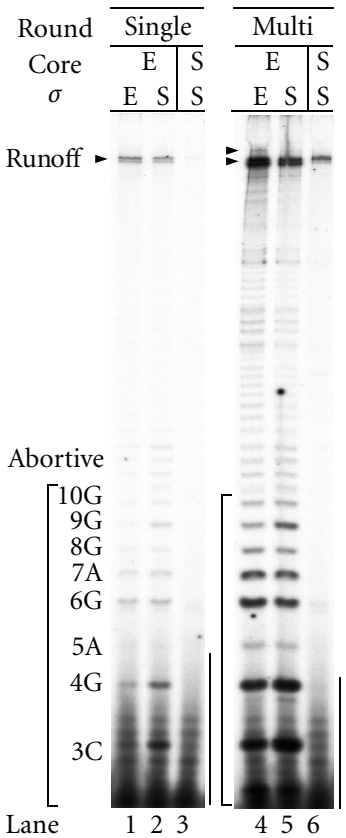

(b)

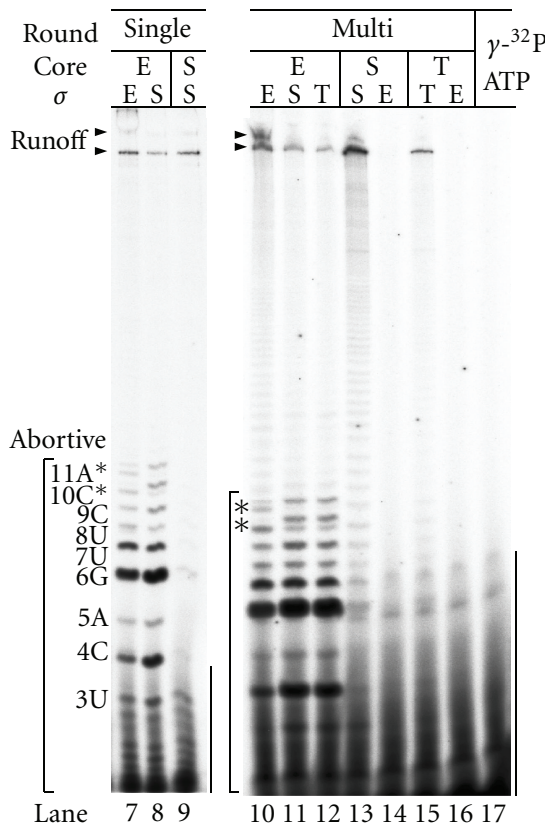

(c)

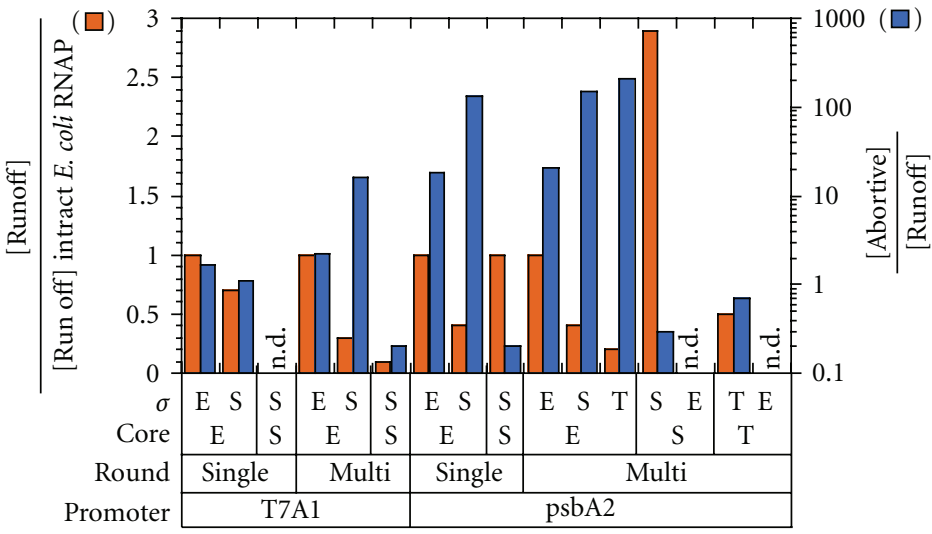

(d)

Figure 2: Transcription from the T7A1 and the psbA2 promoters by cyanobacterial and E. coli RNAPs as well as their chimeric enzymes. (a) The DNA sequences of the T7A1 and the $p s b A 2$ promoters. The putative -10 and -35 elements are underlined, and the transcribed sequences are indicated in uppercase letters. (b) The analysis of transcripts labeled with $\left[\gamma-{ }^{32} \mathrm{P}\right] \mathrm{ATP}$ from the T7A1 promoter with $20 \%$ polyacrylamide in the presence of $7 \mathrm{M}$ urea in TBE buffer. (c) The transcripts from the psbA2 promoter. The round of transcription is indicated at the top of the gels. The runoff and abortive transcripts are indicated by arrowheads and parentheses, respectively. The length and the incorporated nucleotide at its $3^{\prime}$ end of an abortive transcript are indicated on the left margin. Asterisks indicate the abortive transcripts involving misincorporation. The radioactive contaminants that is contained in $\left[\gamma_{-}-32 \mathrm{P}\right]$ ATP are also indicated in lane 17 . (d) The amounts of the run-off transcript normalized by that of the intact E. coli enzymes (red) and the ratio of the amount of abortive transcripts to that of the run-off transcript in logarithmic scale. 


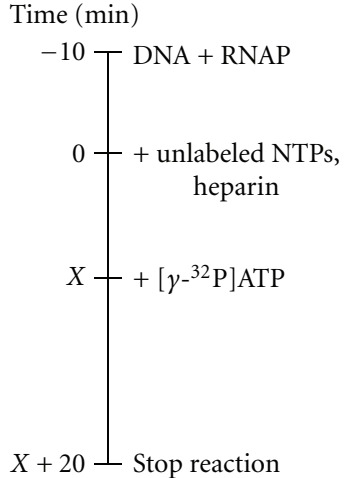

(a)

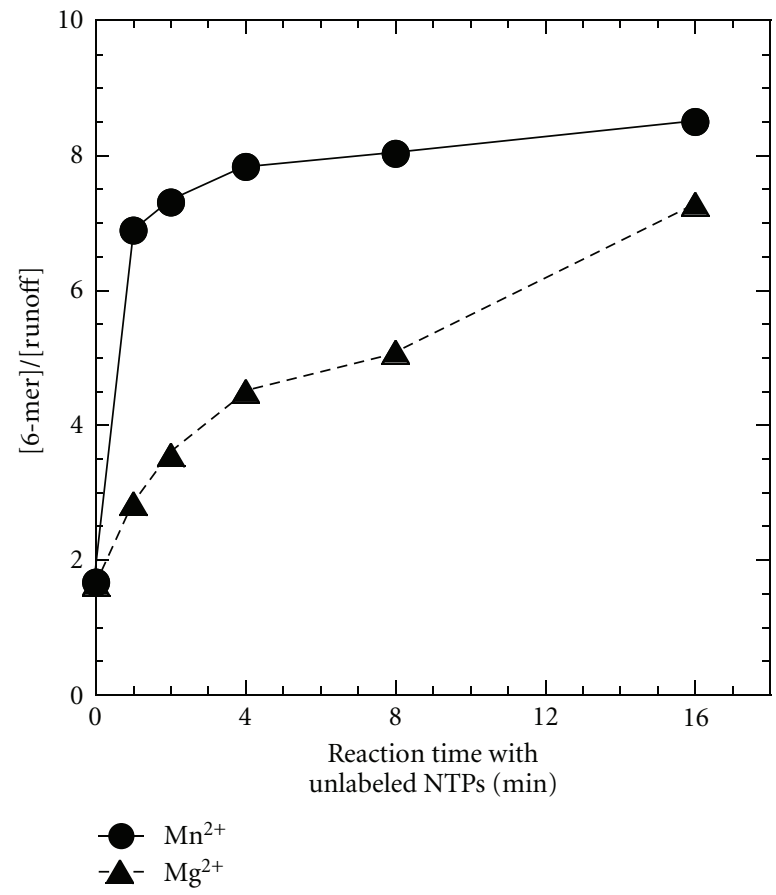

(c)

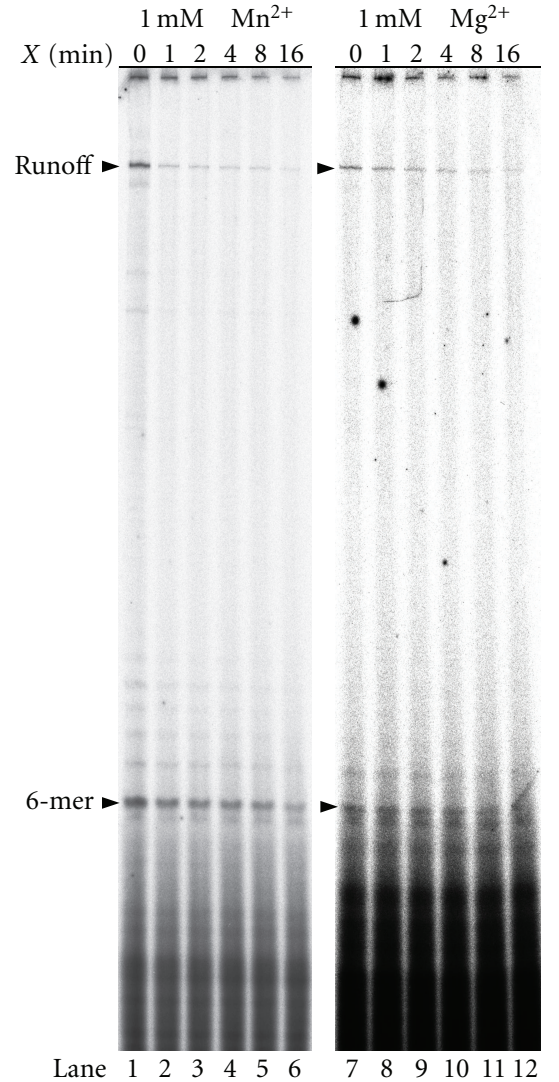

(b)

FIGURE 3: Inverse pulse-labeling assay for detecting persistent abortive synthesis at the $p s b A 2$ promoter by Syn RNAP. (a) Schematic diagram of the assay. The reaction time $X$ is varied. (b) The labeled products synthesized at $1 \mathrm{mM} \mathrm{Mn}^{2+}$ (left) and at $1 \mathrm{mM} \mathrm{Mg}^{2+}$ (right). The runoff transcript and the 6-mer abortive transcript are indicated by arrowheads. (c) The ratios of the amount of 6-mer abortive transcript to that of the runoff transcript were plotted against the reaction time $X$.

The observed small ratios were not specific to the $p s b A 2$ promoter, because in multiround transcriptions from the T7A1 promoter, the ratio for Syn RNAP was also two orders of magnitude smaller than that for E. coli (lanes 4 and 6 in Figure 2). In this experiment, we used the holoenzymes reconstituted from the $\sigma^{A}$ s purified from the overproducing E. coli strains because of low yields of holoenzymes. The observed low activities of abortive transcription are not due to the artifacts of the reconstitution. We independently purified the histidine-tagged holoenzyme of a Synechocystis sp. PCC 6803 and it also produced abortive transcripts as low as the Syn and The RNAP (Figure S1A). In conclusion, cyanobacterial RNAPs are generally much less abortive than E. coli RNAP.

The level of abortive transcription is known to depend on mutations of both core enzyme and $\sigma$ factor [27-29], indicating that both the components are responsible. We addressed the question of which component is more responsible by constructing chimeric holoenzymes. Taking into account the large difference between the levels of cyanobacterial and E. coli RNAPs, we found that the large difference was associated with the core part of RNAP but not $\sigma$ (lanes 2, 5, 8, 11, and 12 in Figure 2). In spite of the absence of detectable transcripts by The enzyme in 


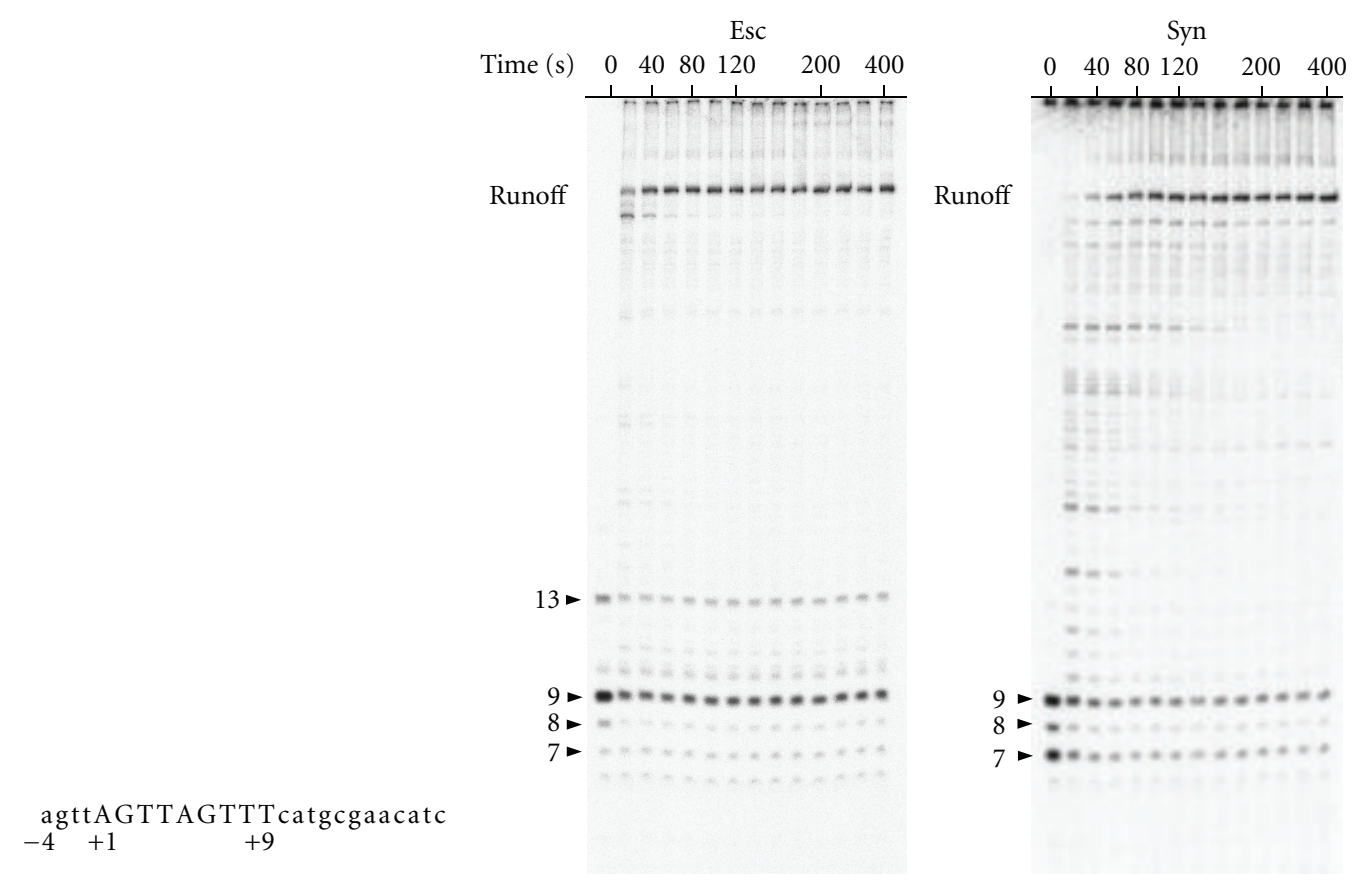

(a)

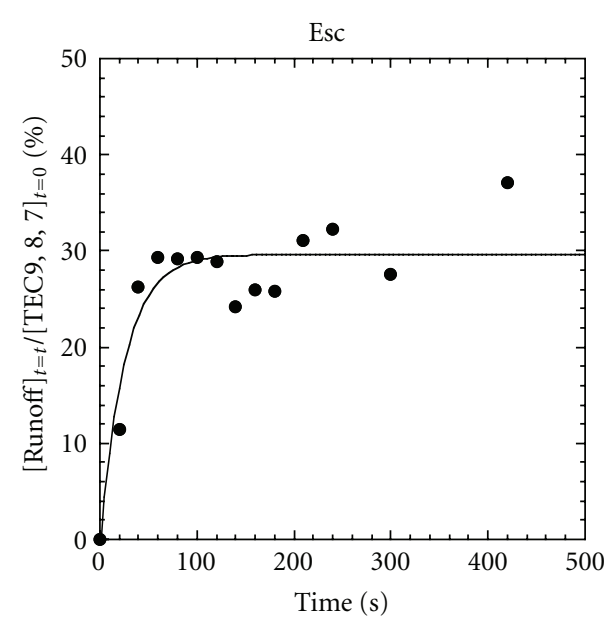

(b)

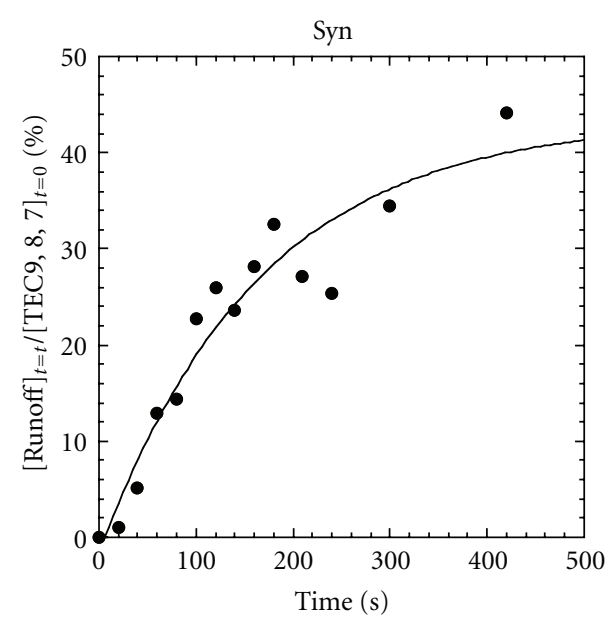

(c)

FIgURE 4: Elongation by the Syn and E. coli TEC9s formed at the $p s b A 2$ promoter. (a) A sequence of the nontemplate strand near the initiation site $(+1)$. The early transcribed region of 9 mer is shown in uppercase letters and the upstream sequence in lower case letters. (b) The transcripts obtained in elongation of the TEC9s which had been labeled with $\left[\gamma_{-}{ }^{32} \mathrm{P}\right]$ ATP. Four NTPs of $100 \mu \mathrm{M}$ each were added to the TEC9 at time zero and incubated for the indicated times. Only this experiment was performed at $25^{\circ} \mathrm{C}$ because of distinct pausing of Syn enzyme. The transcripts existed at time zero as well as the runoff transcripts are indicated by arrowheads. (c) The amount of the runoff transcript at each time point is normalized with the initial amount of TECs and plotted against time. The curves were the best-fit single-exponential ones.

Figure 2, the above conclusion is also applicable to the enzyme because of the results of transcripts labeled with $[\alpha-$ $\left.{ }^{32} \mathrm{P}\right]$ UTP (Figure S1B).

Among the abortive transcripts at the $p s b A 2$ promoter, the $10 \mathrm{nt}$ - and $11 \mathrm{nt}$-transcripts of $E$. coli RNAP accompanied the bands with decreased migration (Figure 2(c)). These transcripts were shown to contain a purine nucleotide instead of the cognate cytosine at Position +10 , a misincorporation, by a chemical cleavage assay (Figure S2). In contrast to abortive transcripts, the runoff transcript did not contain any detectable misincorporation. The chimeric enzymes containing E. coli core enzyme also showed the misincorporation (lanes 7, 8, 10-12 in Figure 2). Such a misincorporation by the E. coli enzyme had already been known for several promoters [19], and thus, this result suggests that the core enzyme is responsible for the misincorporation.

When the enzymes of two different species with different typical growing temperatures are compared, there are no absolute choice of the temperature. Since we focused to the 
difference in the catalytic properties of RNAPs rather than the difference in its role in their growth, we selected the same $37^{\circ} \mathrm{C}$ for in vitro assays. In this way, we can avoid the effect of the different stabilities of DNA duplex in the promoter. The both cyanobacteria grow and survive at $37^{\circ} \mathrm{C}$ although the optimal temperature of The is $55^{\circ} \mathrm{C}$. Another lines of circumstantial evidence for our choice is that the levels of the runoff RNA synthesis are similar for the The and E. coli enzymes for the Syn rrnA promoter (Panel B in Figure S1).

\subsection{Syn RNAP Is Likely to Form Moribund Complex which} Produces Only Abortive Transcripts. For E. coli RNAP, only a part of the promoter complex synthesizes the full-length RNA, while the rest produces the majority of abortive transcripts at the promoter (Figure S3), the latter being named moribund complex [7, 30,31]. To test whether or not the Syn RNAP has a similar property, we carried out the most sensitive assay for detecting the moribund complex: inverse pulse-labeling which monitors the fates of promoter-RNAP complex [30]. In this assay, a single-round transcription from the $p s b A 2$ promoter was started with unlabelled 4NTPs (ATP, CTP, GTP, and UTP) at time zero. The $\gamma_{-}{ }^{32} \mathrm{P}$-labeled initiating ATP was then added at various time points, followed by incubating for a further $20 \mathrm{~min}$ to complete the round (Figure 3(a)). Since the $\left[\gamma_{-}{ }^{32} \mathrm{P}\right]$-labeled runoff and abortive transcripts are both produced only by the RNAP that still survive at the promoter at the time point of adding $\left[\gamma_{-}{ }^{32} \mathrm{P}\right] \mathrm{ATP}$, the ratio of the two kinds of labeled transcripts should reflect the preference of producing abortive transcripts.

As shown in Figures 3(b) and 3(c), the preference becomes stronger at the later time points, showing that the RNAP bound at the promoter at time zero is not homogeneous. Although there is no evidence that cyanobacterial RNAP forms the same moribund complex as E. coli RNAP, which produces only abortive products, a fraction of the Syn enzyme produces abortive transcripts preferentially over others, and the fraction is enriched at the later time points.

\subsection{Syn RNAP Pauses More Frequently and Elongates} Transcript More Slowly Than the E. coli Enzyme. We next compared the elongation by Syn with that by E. coli RNAPs. To isolate elongation from initiation, we used a ternary elongation complex retaining 9-mer transcripts, TEC9 (Figure 4(a)). It was elongated with 4NTPs in the presence of $10 \mathrm{mM}$ $\mathrm{Mg}^{2+}$. The E. coli TEC9 smoothly elongated its transcript, and the elongation was completed at $40 \mathrm{~s}$ (Figure 4(b)). The 6- and 7-mer transcripts existed at time zero, and their amounts did not change, demonstrating that they had been contaminating TEC9. The 9-mer transcript, as well as a part of the 8-mer transcript, was elongated. Therefore, there is no significant pausing of the E. coli enzyme on this template.

In contrast, the elongation of the Syn TEC9 was paused at a number of lengths and was completed at later than $200 \mathrm{~s}$ (Figure 4(b)). When the time courses of syntheses of the run-off transcripts are approximated to single-exponential curves, the elongation of the Syn TEC9 has a time constant

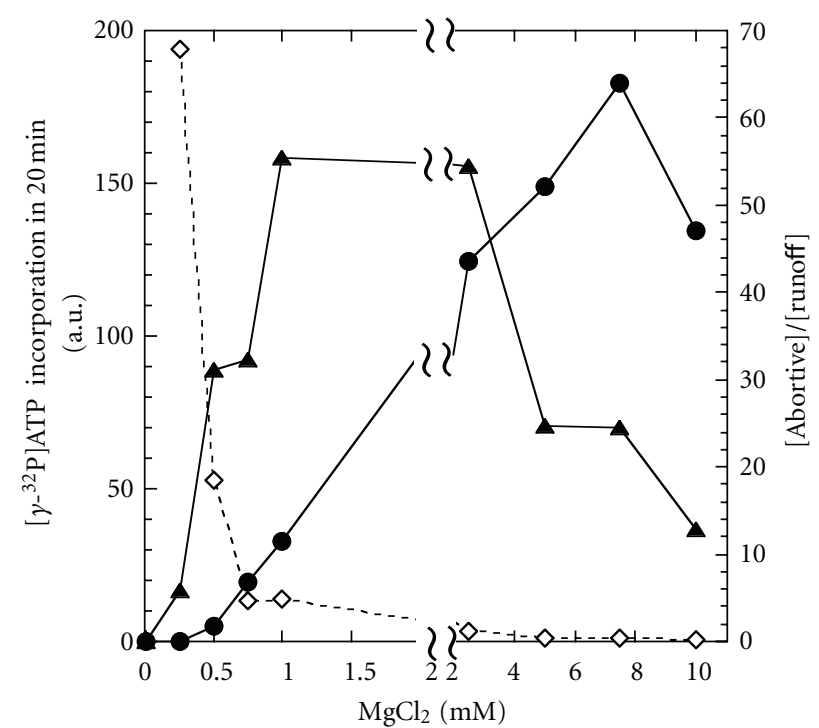

FIgURE 5: Abortive and runoff transcriptions by Syn RNAP at the $p s b A 2$ promoter in the different concentration of $\mathrm{Mg}^{2+}$. The levels of abortive synthesis of 3 to 11 -mer $(\boldsymbol{\Delta})$ and the runoff synthesis $(\bullet)$ in $20 \mathrm{~min}$ in a single-round are plotted against the concentrations of $\mathrm{MgCl}_{2}$. The ratio of the levels $(\diamond)$ is also plotted.

of 6 times longer than that of the E. coli TEC9, that is, time constants of $164 \mathrm{~s}$ compared with $26 \mathrm{~s}$ (Figure $4(\mathrm{c})$ ).

The Syn TEC9 contains more amounts of 7-mer and 8mer transcripts than the E. coli TEC9 at time zero. Since no such short transcripts were found prior to the step of removing NTPs in the preparation (data not shown), the shorter transcript must be generated in the absence of NTP by hydrolysis and/or pyrophosphorolysis of TEC9's, suggesting that the Syn TEC9 had a higher activity of shortening a transcript than E. coli had. In addition, the E. coli TEC9 is contaminated by a 13 -mer transcript. This might be due to the slippage synthesis [32-34] on the $p s b A 2$ promoter, where the segment of AGUU transcribed from +1 to +4 slips back to the agtt template sequence from -4 to -1 , resulting in an addition of 4 base extra sequence at the $5^{\prime}$ end (Figure 4(a)). Again, the Syn enzyme does not catalyze such a misincorporation.

3.5. Sensitivity to $\mathrm{Mg}^{2+}$ Ion of Syn RNAP. The $\mathrm{Mg}^{2+}$ concentration in chloroplast is observed to be changed at dark and at light [35]. In cyanobacteria, the gene expressions are globally repressed at dark, including the $p s b A 2$ expression, [36]. To test the possibility that transcription is directly controlled by $\mathrm{Mg}^{2+}$ concentration, we examined the sensitivity of Syn RNAP to the concentration (Figure 5). According to the increasing $\mathrm{Mg}^{2+}$ concentration from 0.5 to $2.5 \mathrm{mM}$, the level of runoff synthesis was increased by 25 -fold, while the ratio of abortive synthesis to runoff synthesis was decreased to $1 / 15$. In other words, it is possible to control RNAP to produce mainly abortive transcripts at a concentration and mainly mature transcripts in another concentration. However, such control would satisfy several quantitative conditions on the $\mathrm{Mg}^{2+}$ concentration. 
agttagttgaatgtgaaCATC
+19

(a)
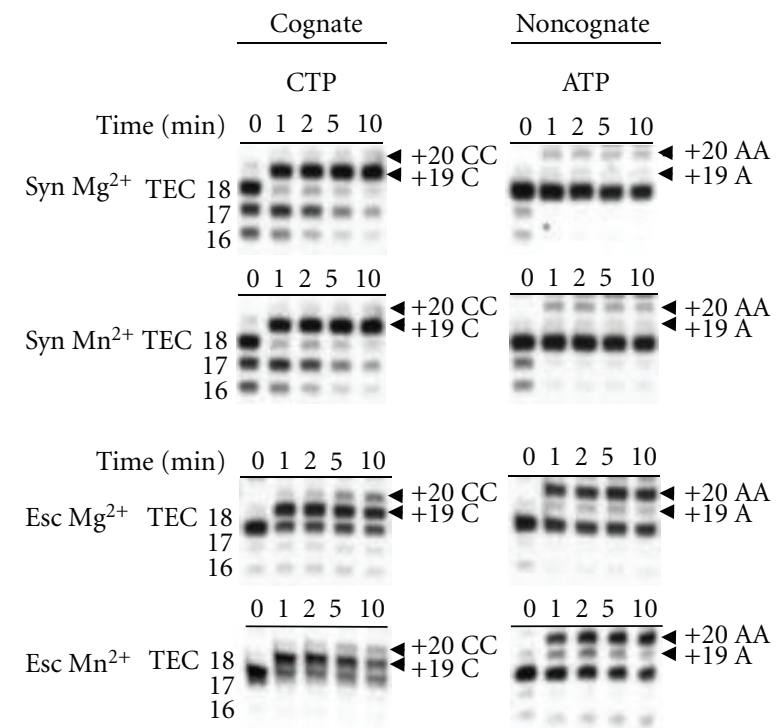

(b)
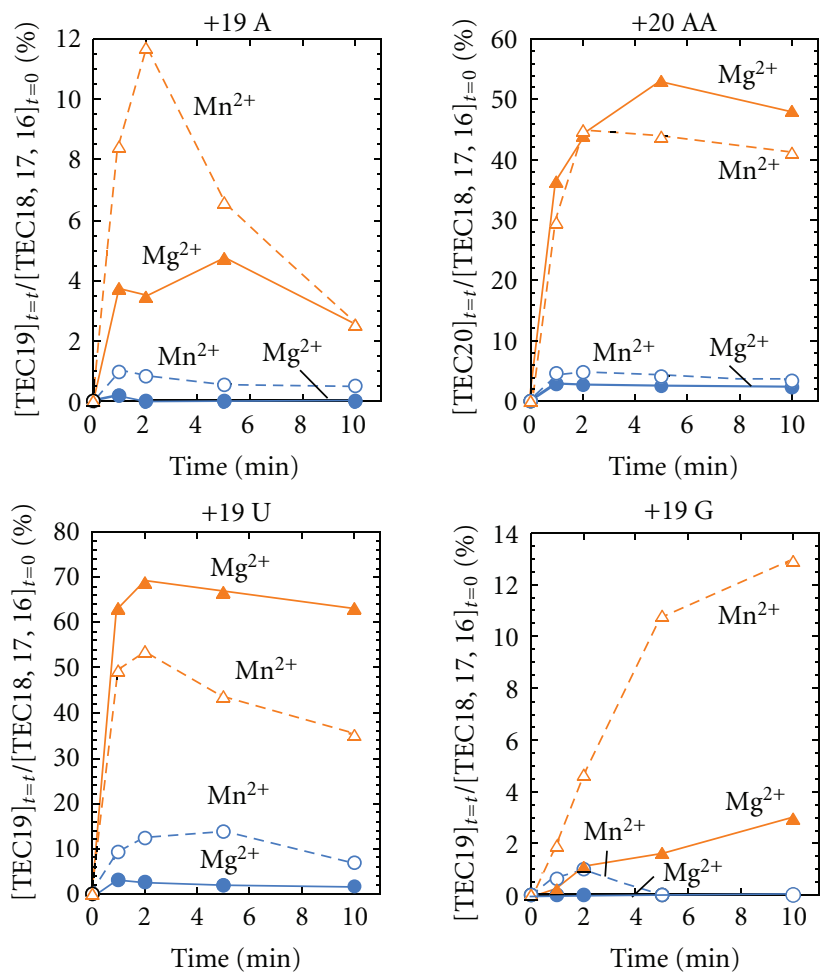

(c)

FIGURE 6: Incorporations of the cognate or noncognate NMP by the Syn and E. coli TEC18s in the presence of $10 \mathrm{mM} \mathrm{Mg}^{2+}$ or $1 \mathrm{mM} \mathrm{Mn}^{2+}$. (a) The sequence of the nontemplate strand from +1 to +22 . Position +19 and the 18 -mer transcript are shown in the bold letter and lower case letters, respectively. (b) The products of TEC18 synthesized in the presence of the cognate CTP and the noncognate ATP (0.5 mM each). Reactions were performed in the presence of $10 \mathrm{mM} \mathrm{MgCl}_{2}$ (upper) or $1 \mathrm{mM} \mathrm{MnCl}_{2}$ (lower). The lengths of transcripts are indicated on the both margins. The incorporated nucleotides are also indicated by the arrowheads in the right margin. (c) The amount of transcript involving misincorporation was shown in the percent of the initial amount of TECs. The TECs of the Syn (blue circle) and E. coli (Esc, orange triangle) were incubated with $0.5 \mathrm{mM} \mathrm{NTP}$ for the indicated times in the presence of $10 \mathrm{mM} \mathrm{MgCl}_{2}$ (filed symbols) or $1 \mathrm{mM} \mathrm{MnCl}_{2}$ (open symbols).

3.6. Syn RNAP Shows Higher Fidelity in Elongation Than the E. coli Enzyme. The results above described show that the Syn RNAP is slower and more accurate in the whole elongation than the E. coli RNAP. We then examined the elongation at the resolution of one nucleotide and arbitrarily selected the elongation at +18 . By using a $p s b A 2$ DNA with cytosine replaced as shown in Figure 6(a), we have prepared TEC18s by the Syn and E. coli enzymes. The elongations of Syn and E. coli TEC18s were carried out for 10 min with CTP, the cognate substrate, or ATP, a noncognate substrate, in the presence of $10 \mathrm{mM} \mathrm{Mg}^{2+}$ or $1 \mathrm{mM} \mathrm{Mn}^{2+}$ (Figure 6(b)). Similarly to TEC9s, a part of the transcript of the Syn TEC18 was shortened during the preparation, as shown in the lanes at time zero in Figure 6(b), probably due to hydrolysis or pyrophosphorolysis in the absence of NTPs. However, in contrast to TEC9, the shortening was not distinct for the E. coli TEC18, demonstrating that the Syn enzyme tends to shorten the retaining transcript more than the E. coli enzyme at Position +18 .

In the presence of the cognate CTP, the Syn and E. coli TEC18s incorporated CMP at Position +19 within $1 \mathrm{~min}$ and then slowly misincorporated CMP at Position +20 (Figure 6(b)). The level of the CMP misincorporation at
10 min was lower for the Syn TEC18 than for the E. coli, being consistent with the more accurate whole elongation by the Syn enzyme than by the E. coli enzyme. In the presence of the noncognate ATP, both the TEC18s incorporated two AMP molecules, the misincorporation at Position +19 and +20 , and again the Syn enzyme was more accurate. The level of the successive two AMP incorporations was by an order of magnitude higher for the E. coli TEC18 than for the Syn one (Figure 6(c)). The Syn TEC18 showed higher fidelity than the E. coli TEC irrespective of the coexisting divalent cations, also for misincorporating UMP and GMP (Figure $5(\mathrm{c}))$. Because this misincorporation may be interpreted as the misincorporation at +19 with the substrate at +20 , this misincorporation could be due to the misalignment mechanism [37, 38].

In conclusion, the Syn enzyme showed higher fidelity than the E. coli one, both in initiation and in elongation, higher shortening activity, and slower rates of elongation. For most sets of substrates and enzymes, misincorporations were enhanced by the replacement of $\mathrm{Mg}^{2+}$ with $\mathrm{Mn}^{2+}$ except for the misincorporation by the E. coli TEC of AMP at +20 (Figure 6(c)). 


\section{Discussion}

As shown in Figure 1(b), cyanobacterial RNAPs have large inserted domains in the $\mathrm{G}$ region of the $\beta^{\prime}$ subunit [14]. In yeast RNAP II, the lack of Rpb9, which can be considered to be the counterpart of a part of the inserted domain of the bacterial $\beta^{\prime}$ subunit, makes elongation faster and fidelity lower [4]. Our results share a similar feature: $E$. coli RNAP bearing smaller insertion elongates faster with lower fidelity than the cyanobacterial enzyme bearing a larger insertion. Therefore, the size of the inserted domain could be a determinant of the rate of elongation and the fidelity of an RNAP.

The holoenzyme containing the primary $\sigma$ factor occupies less than $0.2 \%$ of the soluble proteins in cyanobacteria, and the content is at least 3 to 10 -fold smaller than that in E. coli $[24,39,40]$. This is also consistent with the slower rates of elongation by cyanobacterial RNAP. As proved in $E$. coli, the release of sigma is a time-dependent event costing several seconds [41, 42], but elongation of several kilo base takes several minutes at least. Therefore, slower elongation requires less $\sigma$ factor. In addition, the less formation of moribund complex also decreases the requirement of $\sigma$ factor, because the complex contains the factor.

In E. coli, moribund complex blocks a promoter at the cost of abortive transcripts which are elongated at a rate of orders of magnitude smaller than the productive transcripts [30]. Therefore, repression by forming moribund complex at a promoter is considered to be less wasteful than abortion of long transcripts by elongation pause or immature termination (Figure S3). The Gre factors enable the conversion of moribund complex into productive complex [31] to eliminate the repression by moribund complex [43]. The factors finely tune the levels of some proteins which are important to the growth in rich nutrient conditions $[7,44]$ although the factors are not essential. For example, the transcriptional level of atp operon encoding FoF1ATPase, the main generator of ATP, is reduced to one fourth in the disruptant of the gre genes [7]. Therefore, the Gre factors allow E. coli to make a quick uptake of nutrients at the moderate cost of abortive synthesis.

The two cyanobacteria examined in this study, as well as most cyanobacteria, grow in poorer nutrient conditions than E. coli. They may not be allowed to use the moderate cost as E. coli does with its Gre factors, and this might be the reason why they exceptionally lack the genes orthologous to greA which is widely conserved in eubacteria. Consistently, their RNAPs elongate transcripts slower and form less moribund complex, making the Gre factors insignificant.

If the discussion above is the case, why is the branched pathway preserved in the cyanobacterial RNAP? There could be two answers. The first is that the mechanism is inevitably accompanied with the Brownian ratchet mechanism of RNAP elongation [45]. The other is that the cyanobacterial RNAP may use moribund complex only in limited conditions such as low $\mathrm{Mg}^{2+}$ concentrations. The ratio of abortive to runoff transcripts was 50 or more at a $\mathrm{Mg}^{2+}$ concentration lower than $0.5 \mathrm{mM}$ (Figure 5), which is large enough for the repression by moribund complex to be significant.
The concentration of $\mathrm{Mg}^{2+}$ in a stroma of chloroplast has been measured to change from $0.5 \mathrm{mM}$ at dark to $2 \mathrm{mM}$ at light [35]. This increase by illumination is due to the uptake of $\mathrm{Mg}^{2+}$ from the inner region of the thylakoid membrane, and electrically compensated by the antitransport of proton from a stroma due to photosynthesis $[46,47]$. The cytosolic $\mathrm{pH}$ in cyanobacteria has been measured to change as in the stroma between light and dark $[48,49]$. In contrast to $\mathrm{Mg}^{2+}$, little is known about the variation of $\mathrm{Mn}^{2+}$ concentration in cyanobacterial cells. Although a measured value of the concentration of $\mathrm{Mg}^{2+}$ or $\mathrm{Mn}^{2+}$ in vivo cannot be directly correlated to its concentration effect on in vitro transcription (Figure S4), it is an important clue in comparative studies of RNAPs.

\section{Acknowledgments}

This work was supported by an NIG scholarship and Leaveanest Grant to M. Imashimizu. The authors thank Ms. Harriet Sallach for reading the paper.

\section{References}

[1] V. Sosunov, E. Sosunova, A. Mustaev, I. Bass, V. Nikiforov, and A. Goldfarb, "Unified two-metal mechanism of RNA synthesis and degradation by RNA polymerase," EMBO Journal, vol. 22, no. 9, pp. 2234-2244, 2003.

[2] E. Zaychikov, E. Martin, L. Denissova et al., "Mapping of catalytic residues in the RNA polymerase active center," Science, vol. 273, no. 5271, pp. 107-108, 1996.

[3] J. Hurwitz, L. Yarbrough, and S. Wickner, "Utilization of deoxynucleoside triphosphates by DNA-dependent RNA polymerase of E. coli," Biochemical and Biophysical Research Communications, vol. 48, no. 3, pp. 628-635, 1972.

[4] C. Walmacq, M. L. Kireeva, J. Irvin et al., "Rpb9 subunit controls transcription fidelity by delaying NTP sequestration in RNA polymerase II," Journal of Biological Chemistry, vol. 284, no. 29, pp. 19601-19612, 2009.

[5] S. K. Niyogi, R. P. Feldman, and D. J. Hoffman, "Selective effects of metal ions on RNA synthesis rates," Toxicology, vol. 22, no. 1, pp. 9-21, 1981.

[6] S. K. Niyogi and R. P. Feldman, "Effects of several metal ions on misincorporation during transcription," Nucleic Acids Research, vol. 9, no. 11, pp. 2615-2527, 1981.

[7] M. Susa, T. Kubori, and N. Shimamoto, "A pathway branching in transcription initiation in Escherichia coli," Molecular Microbiology, vol. 59, no. 6, pp. 1807-1817, 2006.

[8] N. Keren, M. J. Kidd, J. E. Penner-Hahn, and H. B. Pakrasi, "A light-dependent mechanism for massive accumulation of manganese in the photosynthetic bacterium Synechocystis sp. PCC 6803," Biochemistry, vol. 41, no. 50, pp. 15085-15092, 2002.

[9] S. Shcolnick and N. Keren, "Metal homeostasis in cyanobacteria and chloroplasts. Balancing benefits and risks to the photosynthetic apparatus," Plant Physiology, vol. 141, no. 3, pp. 805-810, 2006.

[10] M. J. Daly, E. K. Gaidamakova, V. Y. Matrosova et al., "Protein oxidation implicated as the primary determinant of bacterial radioresistance.", PLoS biology, vol. 5, no. 4, p. e92, 2007.

[11] L. A. Allison, M. Moyle, M. Shales, and C. James Ingles, "Extensive homology among the largest subunits of eukaryotic 
and prokaryotic RNA polymerases," Cell, vol. 42, no. 2, pp. 599-610, 1985.

[12] G. Zhang, E. A. Campbell, L. Minakhin, C. Richter, K. Severinov, and S. A. Darst, "Crystal structure of Thermus aquaticus core RNA polymerase at $3.3 \AA$ resolution," Cell, vol. 98, no. 6, pp. 811-824, 1999.

[13] I. Artsimovitch, V. Svetlov, K. S. Murakami, and R. Landick, "Co-overexpression of Escherichia coli RNA polymerase subunits allows isolation and analysis of mutant enzymes lacking lineage-specific sequence insertions," Journal of Biological Chemistry, vol. 278, no. 14, pp. 12344-12355, 2003.

[14] L. M. Iyer, E. V. Koonin, and L. Aravind, "Evolutionary connection between the catalytic subunits of DNA-dependent RNA polymerases and eukaryotic RNA-dependent RNA polymerases and the origin of RNA polymerases," BMC Structural Biology, vol. 3, pp. 1-23, 2003.

[15] A. Goto-Seki, M. Shirokane, S. Masuda, K. Tanaka, and H. Takahashi, "Specificity crosstalk among group 1 and group 2 sigma factors in the cyanobacterium Synechococcus sp. PCC7942: in vitro specificity and a phylogenetic analysis," Molecular Microbiology, vol. 34, no. 3, pp. 473-484, 1999.

[16] M. Imashimizu, M. Hanaoka, A. Seki, K. S. Murakami, and $\mathrm{K}$. Tanaka, "The cyanobacterial principal $\sigma$ factor region 1.1 is involved in DNA-binding in the free form and in transcription activity as holoenzyme," FEBS Letters, vol. 580, no. 14, pp. 3439-3444, 2006.

[17] D. A. Hager, D. J. Jin, and R. R. Burgess, "Use of mono $\mathrm{Q}$ high-resolution ion-exchange chromatography to obtain highly pure and active Escherichia coli RNA polymerase," Biochemistry, vol. 29, no. 34, pp. 7890-7894, 1990.

[18] J. J. Dunn and F. W. Studier, "Complete nucleotide sequence of bacteriophage T7 DNA and the locations of T7 genetic elements," Journal of Molecular Biology, vol. 166, no. 4, pp. 477-535, 1983.

[19] T. Kubori and N. Shimamoto, "Physical interference between Escherichia coli RNA polymerase molecules transcribing in tandem enhances abortive synthesis and misincorporation," Nucleic Acids Research, vol. 25, no. 13, pp. 2640-2647, 1997.

[20] G. J. Schneider and R. Hasekorn, "RNA polymerase subunit homology among cyanobacteria, other eubacteria and archaebacteria," Journal of Bacteriology, vol. 170, no. 9, pp. 41364140, 1988.

[21] G. Schyns, L. Jia, T. Coursin, N. Tandeau De Marsac, and J. Houmard, "Promoter recognition by a cyanobacterial RNA polymerase: in vitro studies with the Calothrix sp. PCC 7601 transcriptional factors RcaA and RcaD," Plant Molecular Biology, vol. 36, no. 5, pp. 649-659, 1998.

[22] W. Kammerer, U. Deuschle, R. Gentz, and H. Bujard, "Functional dissection of Escherichia coli promoters: information in the transcribed region is involved in late steps of the overall process," EMBO Journal, vol. 5, no. 11, pp. 2995-3000, 1986.

[23] M. R. Schaefer and S. S. Golden, "Differential expression of members of a cyanobacterial $p s b A$ gene family in response to light," Journal of Bacteriology, vol. 171, no. 7, pp. 3973-3981, 1989.

[24] S. Imamura, S. Yoshihara, S. Nakano et al., "Purification, characterization, and gene expression of all sigma factors of RNA polymerase in a cyanobacterium," Journal of Molecular Biology, vol. 325, no. 5, pp. 857-872, 2003.

[25] A. J. Carpousis and J. D. Gralla, "Cycling of ribonucleic acid polymerase to produce oligonucleotides during initiation in vitro at the lac UV5 promoter," Biochemistry, vol. 19, no. 14, pp. 3245-3253, 1980.
[26] D. E. Johnston and W. R. McClure, "Abortive initiation of in vitro RNA synthesis on bacteriophage DNA," in RNA Polymerase, R. Losick and M. Chamberlin, Eds., pp. 413-428, Cold Spring Harbor Laboratory Press, New York, NY, USA, 1976.

[27] L. M. Heisler, G. Feng, D. J. Jin, C. A. Gross, and R. Landick, "Amino acid substitutions in the two largest subunits of Escherichia coli RNA polymerase that suppress a defective rho termination factor affect different parts of the transcription complex," Journal of Biological Chemistry, vol. 271, no. 24, pp. 14572-14583, 1996.

[28] K. S. Murakami, S. Masuda, and S. A. Darst, "Structural basis of transcription initiation: RNA polymerase holoenzyme at 4 A resolution," Science, vol. 296, no. 5571, pp. 1280-1284, 2002.

[29] R. Sen, H. Nagai, V. J. Hernandez, and N. Shimamoto, "Reduction in abortive transcription from the $\lambda \mathrm{P}(\mathrm{R})$ promoter by mutations in region 3 of the $\sigma 70$ subunit of Escherichia coli RNA polymerase," Journal of Biological Chemistry, vol. 273, no. 16, pp. 9872-9877, 1998.

[30] T. Kubori and N. Shimamoto, "A branched pathway in the early stage of transcription by Escherichia coli RNA polymerase," Journal of Molecular Biology, vol. 256, no. 3, pp. 449-457, 1996.

[31] R. Sen, H. Nagai, and N. Shimamoto, "Polymerase arrest at the $\lambda \mathrm{P}(\mathrm{R})$ promoter during transcription initiation," Journal of Biological Chemistry, vol. 275, no. 15, pp. 10899-10904, 2000.

[32] S. Borukhov, V. Sagitov, C. A. Josaitis, R. L. Gourse, and A. Goldfarb, "Two modes of transcription initiation in vitro at the rrnB P1 promoter of Escherichia coli," Journal of Biological Chemistry, vol. 268, no. 31, pp. 23477-23482, 1993.

[33] J. P. Jacques and M. M. Susskind, "Pseudo-templated transcription by Escherichia coli RNA polymerase at a mutant promoter," Genes and Development, vol. 4, no. 10, pp. 18011810, 1990.

[34] R. C. Parker, "Synthesis of in vitro ColE1 transcripts with 5 '-terminal ribonucleotides that exhibit noncomplementarity with the DNA template," Biochemistry, vol. 25, no. 21, pp. 6593-6598, 1986.

[35] S. Ishijima, A. Uchibori, H. Takagi, R. Maki, and M. Ohnishi, "Light-induced increase in free $\mathrm{Mg}^{2+}$ concentration in spinach chloroplasts: measurement of free $\mathrm{Mg}^{2+}$ by using a fluorescent probe and necessity of stromal alkalinization," Archives of Biochemistry and Biophysics, vol. 412, no. 1, pp. 126-132, 2003.

[36] H. Ito, M. Mutsuda, Y. Murayama et al., "Cyanobacterial daily life with Kai-based circadian and diurnal genome-wide transcriptional control in Synechococcus elongatus," Proceedings of the National Academy of Sciences of the United States of America, vol. 106, no. 33, pp. 14168-14173, 2009.

[37] E. Kashkina, M. Anikin, F. Brueckner et al., "Template Misalignment in Multisubunit RNA Polymerases and Transcription Fidelity," Molecular Cell, vol. 24, no. 2, pp. 257-266, 2006.

[38] R. T. Pomerantz, D. Temiakov, M. Anikin, D. G. Vassylyev, and W. T. McAllister, "A mechanism of nucleotide misincorporation during transcription due to template-strand misalignment," Molecular Cell, vol. 24, no. 2, pp. 245-255, 2006.

[39] M. Jishage and A. Ishihama, "Regulation of RNA polymerase sigma subunit synthesis in Escherichia coli: intracellular levels of $\sigma 70$ and $\sigma 38$," Journal of Bacteriology, vol. 177, no. 23, pp. 6832-6835, 1995.

[40] Y. Iwakura, K. Ito, and A. Ishihama, "Biosynthesis of RNA polymerase in Escherichia coli. I. Control of RNA polymerase content at various growth rates," Molecular and General Genetics, vol. 133, no. 1, pp. 1-23, 1974. 
[41] N. Shimamoto, T. Kamigochi, and H. Utiyama, "Release of the $\sigma$ subunit of Escherichia coli DNA-dependent RNA polymerase depends mainly on time elapsed after the start of initiation, not on length of product RNA," Journal of Biological Chemistry, vol. 261, no. 25, pp. 11859-11865, 1986.

[42] M. Raffaelle, E. I. Kanin, J. Vogt, R. R. Burgess, and A. Z. Ansari, "Holoenzyme switching and stochastic release of sigma factors from RNA polymerase in vivo," Molecular Cell, vol. 20 , no. 3, pp. 357-366, 2005.

[43] R. Sen, H. Nagai, and N. Shimamoto, "Conformational switching of Escherichia coli RNA polymerase-promoter binary complex is facilitated by elongation factor GreA and GreB," Genes to Cells, vol. 6, no. 5, pp. 389-401, 2001.

[44] E. Stepanova, J. Lee, M. Ozerova et al., "Analysis of promoter targets for Escherichia coli transcription elongation factor GreA in vivo and in vitro," Journal of Bacteriology, vol. 189, no. 24, pp. 8772-8785, 2007.

[45] G. Bar-Nahum, V. Epshtein, A. E. Ruckenstein, R. Rafikov, A. Mustaev, and E. Nudler, "A ratchet mechanism of transcription elongation and its control," Cell, vol. 120, no. 2, pp. 183193, 2005.

[46] G. H. Krause, "Light induced movement of magnesium ions in intact chloroplasts. Spectroscopic determination with Eriochrome Blue SE," Biochimica et Biophysica Acta, vol. 460, no. 3, pp. 500-510, 1977.

[47] G. Hind, H. Y. Nakatani, and S. Izawa, "Light dependent redistribution of ions in suspensions of chloroplast thylakoid membranes," Proceedings of the National Academy of Sciences of the United States of America, vol. 71, no. 4, pp. 1484-1488, 1974.

[48] H. W. Heldt, K. Werdan, M. Milovancev, and G. Geller, "Alkalization of the chloroplast stroma caused by light dependent proton flux into the thylakoid space," Biochimica et Biophysica Acta, vol. 314, no. 2, pp. 224-241, 1973.

[49] S. Belkin, R. J. Mehlhorn, and L. Packer, "Proton gradients in intact cyanobacteria," Plant physiology, vol. 84, pp. 25-30, 1987. 

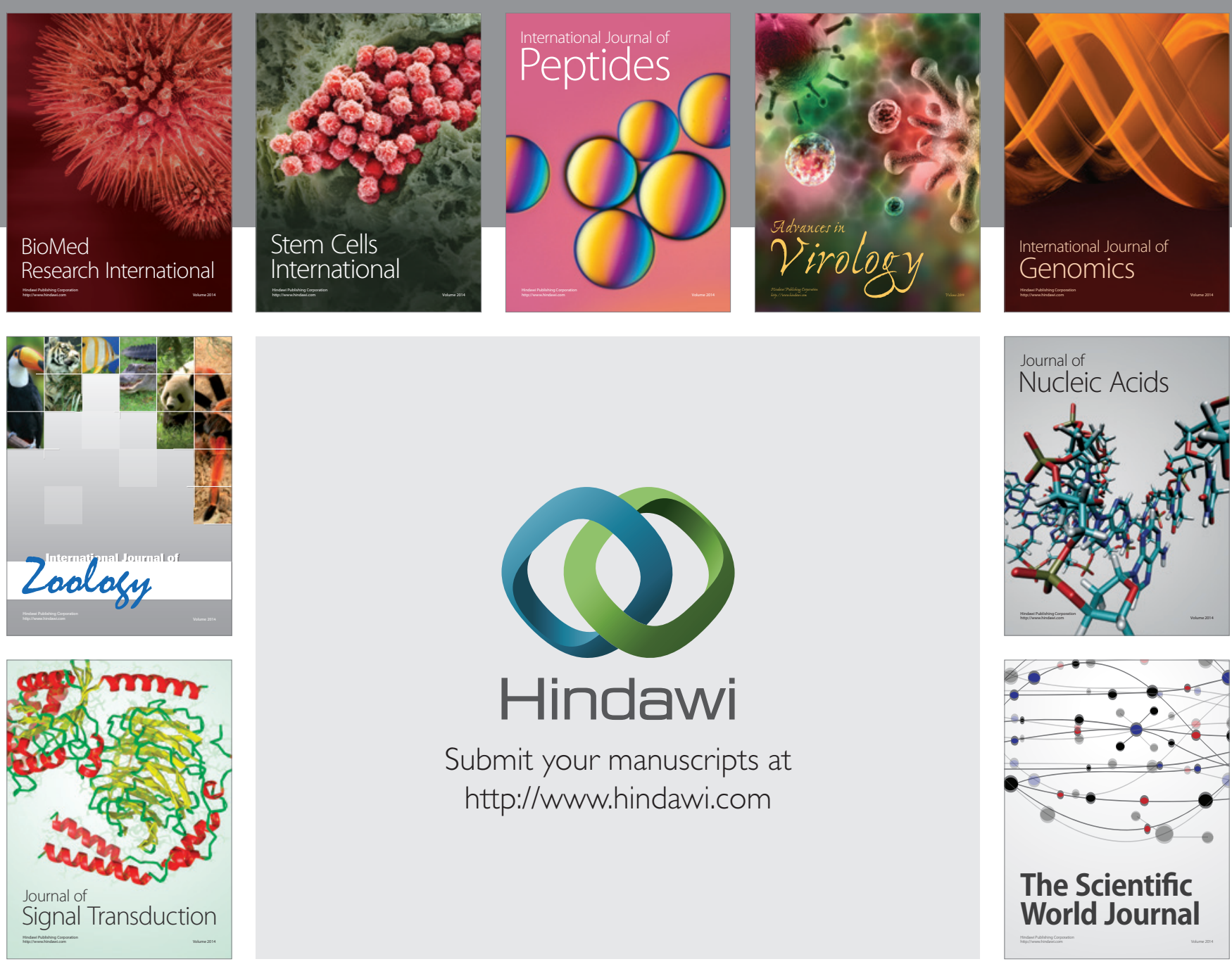

Submit your manuscripts at

http://www.hindawi.com
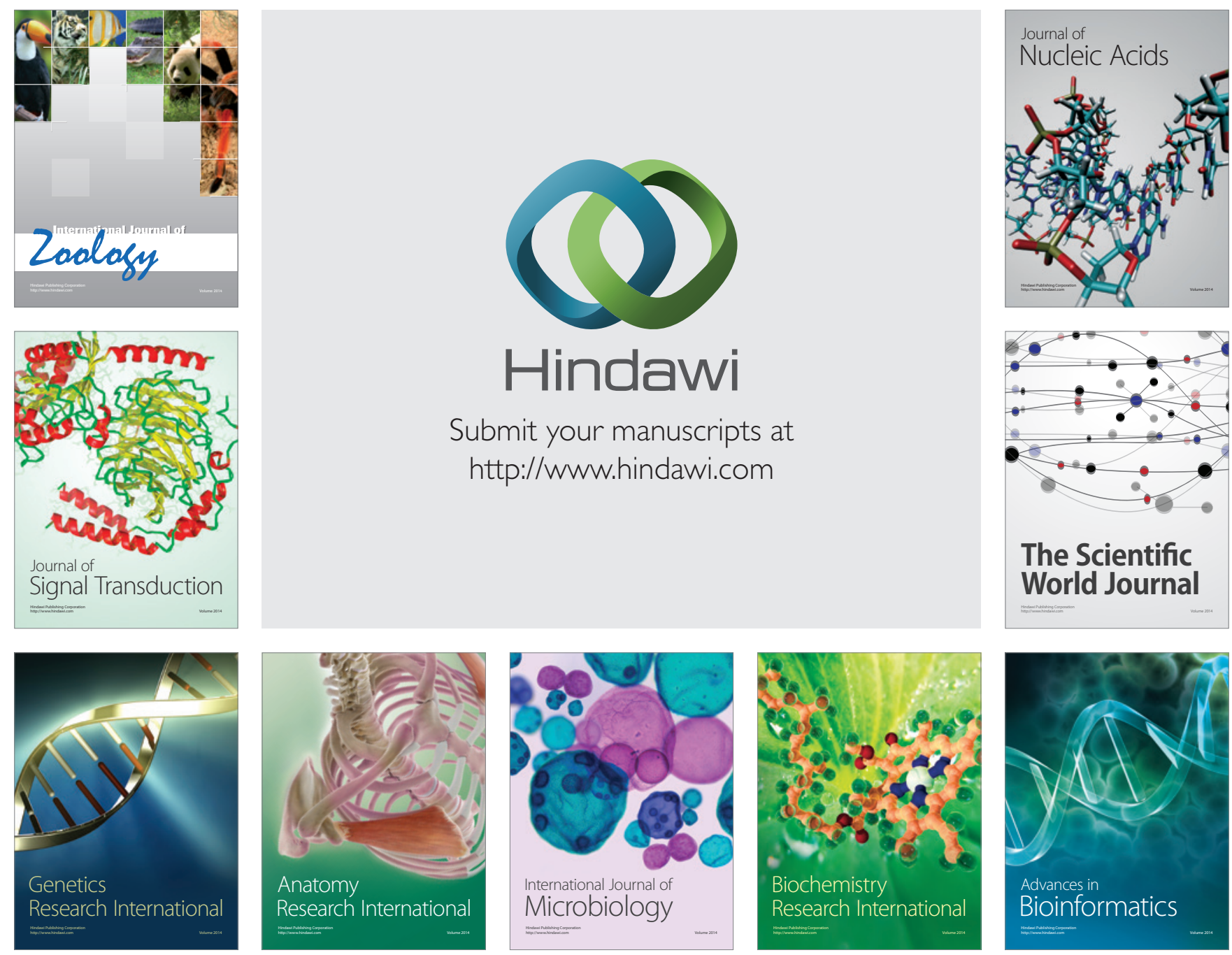

The Scientific World Journal
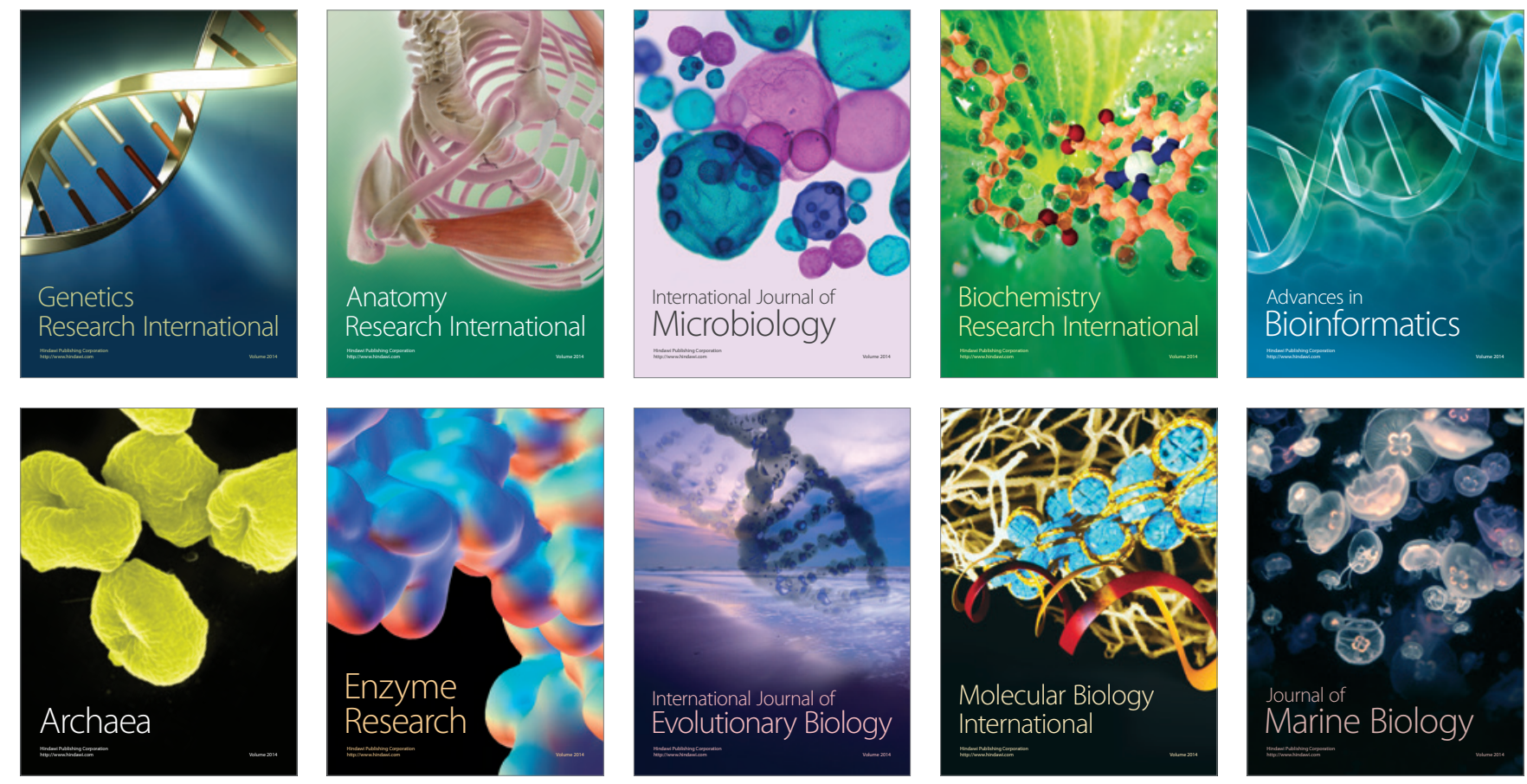